Genesis and stages of renovation in architecture and urban planning of "new cities" (based on the example of Aktau (Shevchenko)

\title{
GENESIS AND STAGES OF RENOVATION IN ARCHITECTURE AND URBAN PLANNING OF "NEW CITIES" BASED ON THE EXAMPLE OF AKTAU (SHEVCHENKO)
}

Scientific paper / Znanstveni rad

Alina Haritonova

(Received: 14 June 2018; accepted: 16 November 2018)

Odessa State Academy of Building and Architecture, Assistant professor, PhD

Larysa Shuldan

Lviv Polytechnic National University, Institute of Architecture, Assistant professor, PhD.

Corresponding author: shuldanlarisa@gmail.com

Andrii Shtendera

Lviv Polytechnic National University, Institute of Architecture, Postgraduate student

\begin{abstract}
This article deals with the problems of cities built during the second half of the 20th century, which in the literature, are referred to as "new." Today, they have changed or have not yet determined the city-forming vector of development, the basis of which was initially, as a rule, large-scale industrial complexes. The search for new ideas and design solutions lies in grounding scientific research and conducting design workshops to create a bank of architectural and town-planning proposals. Based on the example of the city of Shevchenko (now Aktau), a study of its architectural genesis and the phenomenon of the rapid implementation of a project, which received the highest architectural award, namely, the Patrick Abercrombie Prize, the modern strategy of renovation, and development of the city is considered. Positive experience requires study, and it can be applied to "new" cities and partially applied to historically formed cities.
\end{abstract}

Keywords: new city; Patrick Abercrombie Prize; urban planning; living environment; international project workshops

\section{UTJECAJ GENEZA I ETAPE OBNOVE ARHITEKTURE I URBANIZMA "NOVIH GRADOVA" NA PRIMJERU AKTAU (SHEVCHENKO)}

Sažetak: U radu se govori o problemima gradova izgrađenih u drugoj polovini prošloga stoljeća, koje literatura navodi kao "nove". Do danas su ti gradovi prošli određene promjene ili još nisu odredili smjer razvoja grada, koji je od osnutka bio, u pravilu, vođen izgradnjom velikih industrijskih kompleksa. Znanstveno istraživanje i urbanističkoarhitektonske radionice imaju cilj kreirati bazu arhitektonskih i urbanističkih prijedloga. Na primjeru grada Shevchenko (sada Aktau), kroz istraživanje arhitektonske geneze i fenomena brze provedbe projekta, koji je dobio najvišu arhitektonsku nagradu Patricka Abercrombieja, razmatra se nova strategija obnove i razvoja grada. Pozitivno iskustvo zahtjeva istraživački pristup koji se može primijeniti ne samo u "novim", već i u povijesnim gradovima.

Ključne riječi: novi grad; Nagrada Patrick Abercrombie; urbanističko planiranje; životni okoliš; međunarodne arhitektonske radionice 
Genesis and stages of renovation in architecture and urban planning of "new cities" (based on the example of Aktau (Shevchenko)

\section{INTRODUCTION}

An ambiguous urban heritage was left during the second half of the 20th century in the post-Soviet and former socialist republics. Because of large-scale industrial growth and the peculiarities of socio-economic processes, the rates of urbanization in the USSR were 2-3 times higher than those of Western countries [1]. For a mature industrial society, "new cities" were built. Cities rebuilt from scratch, in deserts or clean fields, around today's uncompetitive areas of industrial complexes are extremely problematic and currently degrading. It can be considered rare for such settements to be sustainable in terms of development and social viability. Even those that survived during the change in systems are morally and physically outdated, and a new modern vector of development has not been found. They have exacerbated the problems of social and socio-natural development, particularly the environment, energy, and transport. The return of the social structure of community centers in neighborhoods, the restoration of their architectural appearance is also necessary. The most viable of these are seaside cities. However, the uncontrolled and chaotic expansion of private buildings during the last 30 years has led to a loss of recreational coastal zones in these areas. A positive example in this regard is the unique history of a city built during the 1960s and 1970s in a lifeless desert as a search for answers to modern challenges and a desire to survive, namely, the city of Shevchenko (Aktau). In the areas of architecture and urban planning, as a syncretic approach toward the development and management of a modern city, it is time to research, through a multilateral analysis, the scientific findings and new ideas discovered in the buildings of this city, which were conceived by a talented team of designers, and combine their inspiration and urbanized vision with current scientific achievements.

\section{LITERATUREREVIEW}

We live in an increasingly urban world. The United Nations Deparment of Economic and Social Affairs (UN DESA) published its 2018 Revision of the World Urbanization Prospects, which showed that $55 \%$ of the global population is already living in cities, and this value will increase to around $68 \%$ by 2050 [2]. The European Commission $(2001,2006,2010)$ proposed the following indicators of sustainable urban development: satisfaction of residents from community life, city participation in global climate change, urban mobility and public transport, accessibility of services and public spaces, local air quality, availability of children to educational institutions, quality management of local power and local business, noise pollution, effective management of territories, products that promote sustainable development, and the consumption of nonrenewable resources and renewable energy [3]. Another European document, Indicators for Sustainable Cities - European Commission (1999), proposed 15 indicators of sustainable urban development, which are divided into three groups:

1) global environment (global climate, acidification of soils, ecosystem toxicity, water status, energy consumption);

2) local quality of life (air quality, local changes in the environment, waste management, urban mobility);

3) other indicators (public justice, housing conditions, public safety, economic development, quality of public space and planting of greenery, involvement of inhabitants in urban processes).

The Global Future Council on Cities and Urbanization has identified three levels of relevance to urban development [4]: "physical" components, "digital" elements, and "environmental" factors. A method for estimating the urban form for an assessment of the city form in its numerous developments is also relevant in this day [5]. Methodologies for an analysis of urban spaces covers the subject focused upon by Professor Bill Hillier [6]. At the end of the 20th century to the beginning of the 21st century in Ukraine and Kazakhstan, scientific works were published, namely, those by I. Fomin, A. Kashchenko, V. Yezhov, O. Drapikovs'kyy, L. Ivanova, O. Boyko-Boychuk, V. Hroysman, V. Timochin, M. Habrel', V. Vadimov, H. Petryshyn, V. Didyk, L. Shuldan and A. Pavliv, who have been devoted to general theoretical urban planning questions, the methodological bases of urbanized systems, their self-organization, and the harmonious orientation of evolution [7-13]. These works do not fully reflect the current trends, but take into account the realifies and features of the design of the previous stage of urban development in a post-Soviet space.

The historical stages of the construction of the city of Shevchenko were partially based on the development of the Mangyshlak power plant, which is a life-supporting component of the region. [14, 15]. Haritonova, A, Shuldan, L, Shtendera, A 
Genesis and stages of renovation in architecture and urban planning of "new cities" (based on the example of Aktau (Shevchenko)

However, the laws under which the cities previously functioned no longer work. Creating a living environment that takes into account the challenges of modernity must satisfy the high material and spiritual needs of humans, and stimulate the development of the individual and society as a whole, which is a subject of intensified research for contemporary sociologists, city planners, and architects.

\section{BASIC THEORY}

A significant place in the formation of a spiritually optimal living environment of the city, namely imagery of the subject-spatial environment of a person, belongs to the author's urban planning idea of goal-oriented architects, which when implemented will maintain a social function for many decades and even centuries. A city is a powerful image that acts on human consciousness and enters into a synthesis with modern life of a certain historical stage of the emergence, growth, and development of the city [16].

The emergence of new cities is natural, and as a rule, is associated with the development of new areas (localities) or new resources. The cause of their occurrence served as the dominant town-forming factor. Professions of new cities are quite diverse (Table 1). Few cities are born as capitals (Table 1, No. 18), and most began their lives as mono- or multi-functional industrial centers (Table 1, Nos. 1-11, 13-16). Less commonly, there may be research centers present in cities (Table 1, Nos. 12 and 17), attracting other industries.

Table 1 Dominant city-forming factors of some "new cities" formed during the second half of the 20th century

\begin{tabular}{|c|c|c|c|c|c|}
\hline & $\begin{array}{l}\text { Modern name of the } \\
\text { city }\end{array}$ & $\begin{array}{l}\text { Original name of the city } \\
\text { | village | }\end{array}$ & $\begin{array}{c}\text { Year of } \\
\text { establishment }\end{array}$ & Country & Town-forming factor \\
\hline 1 & Aktau & Shevchenko /Guryev-20/ & 1961 & Kazakhstan & Oil, gas, uranium ore \\
\hline 2 & Navoiy & Navoiy & 1958 & Uzbekistan & Mining and metallurgical \\
\hline 3 & Lički Osik & Teslingrad & 1951 & Croatia & Metallurgy \\
\hline 5 & Lesnoy & $\begin{array}{l}\text { Sverdlovsk-45 } \\
\text { Gorny }\end{array}$ & 1950 & Russia & Military industry \\
\hline 6 & Mirny & Mirny & 1955 & $\begin{array}{l}\text { Russia } \\
\text { Yakutia }\end{array}$ & Diamond mining \\
\hline 7 & $\begin{array}{l}\text { Janaozen } \\
\text { (Zhanaozen) }\end{array}$ & Novy Uzen & 1964 & Kazakhstan & Oil, gas \\
\hline 8 & Rudny & Rudnogorsk & 1957 & Kazakhstan & Iron ore production \\
\hline 9 & Serebryansk & Serebryanka & 1962 & Kazakhstan & Hydroelectric power station \\
\hline 10 & Kurchatov & Kurchatov & 1968 & Russia & Kursk nuclear power plant \\
\hline 11 & Stepnogorsk & $\begin{array}{l}\text { Iselinograd-2b, IVlakinsk- } \\
2\end{array}$ & 1959 & Kazakhstan & Uranium ore processing \\
\hline 12 & Priozersk & $\begin{array}{l}\text { Korzhyn-Tybek, } \\
\text { Koktas }\end{array}$ & 1956 & Kazakhstan & Research testsite \\
\hline 13 & Pripyat & Pripyat & 1970 & Ukraine & $\begin{array}{l}\text { Chernobyl nuclear power } \\
\text { plant } \mid \text { abandoned city } \mid\end{array}$ \\
\hline $\begin{array}{l}14 \\
15\end{array}$ & $\begin{array}{c}\text { Enerhodar } \\
\text { Yuzhnoukrainsk }\end{array}$ & $\begin{array}{c}\text { Enerhodar } \\
\text { Kostiantynivka -2 }\end{array}$ & $\begin{array}{l}1970 \\
1975\end{array}$ & $\begin{array}{l}\text { Ukraine } \\
\text { Ukraine }\end{array}$ & $\begin{array}{l}\text { State regional power station } \\
\text { Nuclear power plant }\end{array}$ \\
\hline 16 & Slavutych & Slavutych & 1986 & Ukraine & $\begin{array}{l}\text { Resettlement ofChernobyl } \\
\text { workers }\end{array}$ \\
\hline 17 & Innopolis & Innopolis & 2012 & $\begin{array}{l}\text { Russia } \\
\text { Tatarstan }\end{array}$ & $\begin{array}{c}\text { Research and experimental } \\
\text { center }\end{array}$ \\
\hline 18 & Magas & Magas & 1995 & $\begin{array}{l}\text { Russla } \\
\text { Ingushetia }\end{array}$ & The capital of Ingushetia \\
\hline
\end{tabular}

Studies on the aspects of development, architectural renovation, and urban planning are relevant for a number of new cities of the former USSR, countries formed after its collapse, and countries of the former socialist camp [17-20].

Building a new city begins with a project. Thus, architects have played an important role in determining the structure of an urban environment and the appearance of a city. In 1961, a new city, Shevchenko, was Haritonova, A, Shuldan, L, Shtendera, A 
Genesis and stages of renovation in architecture and urban planning of "new cities" (based on the example of Aktau (Shevchenko)

founded on the Mangyshlak Peninsula. Within a short period of time, oil, gas, chemical, and other industries developed on the peninsula, a place that was nearly untamed by civilization. The general project organization of the new city was one of the institutes of the Ministry of Medium Machine Building of the USSR, namely, the Leningrad Design Institute, specifically the Architectural Planning Studio, which was created in 1962 specifically for projects of the "southern cities" of Shevchenko in Kazakhstan and Navoi in Uzbekistan, which were at the time the modest villages of Melovoe and Kermine. In 1950, the "secret" project organization "Lengiprostroy," referred to the "First Main Directorate" at the Council of Ministers of the USSR, and later, the Ministry of Medium Machine Building. Work on the concept of the city began in 1961 (by the designers MI Levin, EF Usanov, and others) [21, 22]. This urban planning school was formed under the unique conditions of the Soviet Union, where the state was a regular customer of new designs, which guaranteed the planned implementation of such largescale projects.

When creating the new city, the architects and urban planners laid the prospect of its growth, given that the geographical and economic conditions of this location on the Caspian coast would inevitably lead to the transformation of the village into a large city. It took only two years for the settlement to receive the official status of a city (the date of birth of the city is 1963), despite the fact that the pre-project analysis showed that there was no great prospect for the development of a residential area in a waterless region. Geomorphologically, the city of Aktau (Shevchenko) is located at the western end of the Mangyshlak plateau, which is the slope of the second marine abrasion terrace. The main physico-geological processes that formed the modern face of the plateau are the exogenous processes of linear erosion. The climate is continental. The influence of the waters of the Caspian Sea is expressed in a slight increase in air humidity, and a decrease in the annual and daily temperature amplitudes. The territory belongs to an arid region with an average annual precipitation of $172 \mathrm{~mm}$ [23]. The scale of implementation regarding the idea of building the city is shown in the swiftness and effectiveness of its industrial prospects. The city-forming base of the city was the construction of modern industries and natural resources. At the same time, the geographical distance and a lack of fresh water required the production of energy and water based on atomic energy. A nuclear complex has become a fundamental infrastructure base in parallel with the construction of transport routes.

The problem of a lack of natural sources of drinking water was solved thanks to the construction of an industrial seawater desalination complex at a nuclear power plant (MAEK) with the world's first atomic desalination plant, which has a capacity of $120000 \mathrm{~m}^{3}$ of water per day. Designed for a large city, the complex created favorable conditions for the further development of Aktau. Moreover, the issue of green residential complexes was resolved, and in 1971 an experimental botanical garden was created, which is a unique natural complex of the peninsula. Aware of the upcoming problems regarding fresh water in the world, it can be argued today that Shevchenko's experience would be key to solving these problems in the future [23].

With the improvement in living conditions, the population of the city increased from 8000 inhabitants at the beginning of construction to over 40000 in 1969 [1]. As at 2017, the international composition of the population has been preserved and exceeds 187000. [21].

It is interesting to note that, during the Soviet period, more than 60 new cities emerged in Kazakhstan
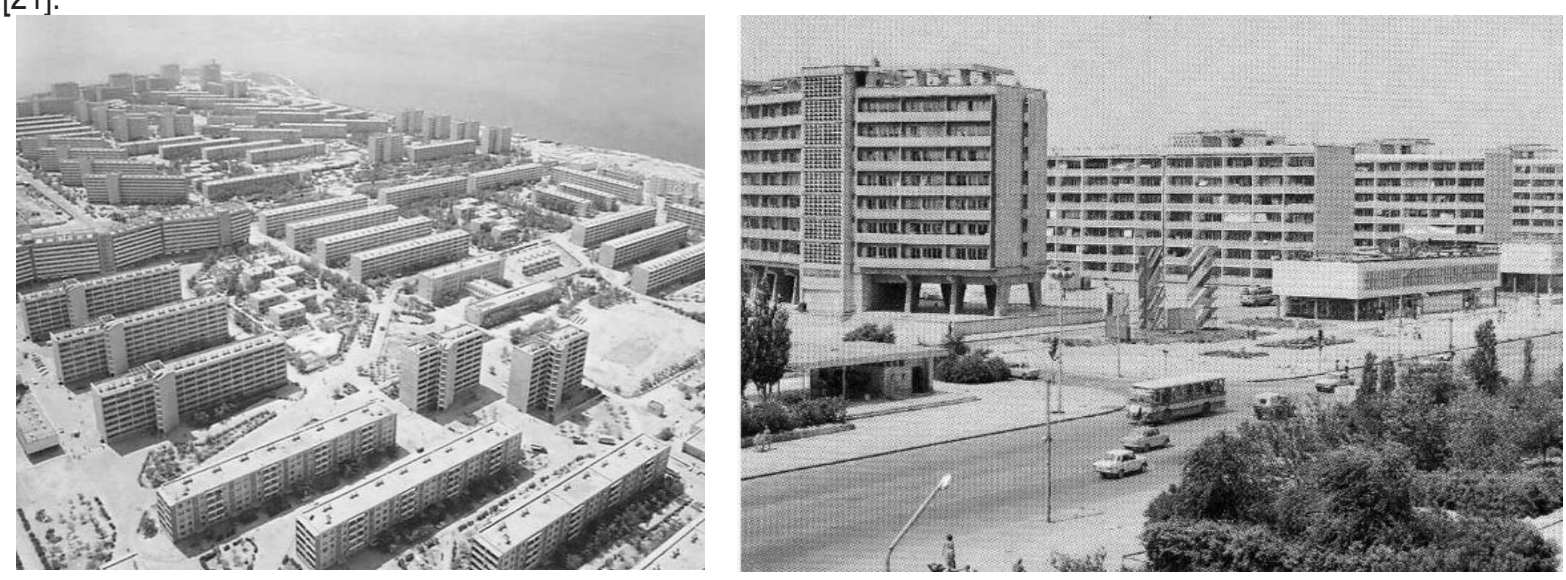

Figure 1 General view of the first microdistricts of the city of Shevchenko during the 1970s [14]

Haritonova, A, Shuldan, L, Shtendera, A

https://doi.org/10.13167/2018.17.4 
Genesis and stages of renovation in architecture and urban planning of "new cities" (based on the example of Aktau (Shevchenko)

The main planning principle of the design of Shevchenko was in the open dynamic scheme of the development of the city, which did not impose limitations on its growth. A phased development system was originally incorporated into the planning organization of the territory of the new city, in which several neighborhoods form a residential area with its center, as well as engineering and social service systems. The enlarged scale of the projected urban space sets its definite step for the growth of the city along the seashore [14]. The development was carried out using microdistricts (Figure 1), each of which provides for the accommodation of 10,000 to 15,000 people with a full range of services, transportation, areas of employment, and public centers, located by taking into account rational human services. The size of each neighborhood was dictated by the normative and most rational social and living services for the population; in addition, preschools and schools are located within the territory of the neighborhood, providing regulatory radii of free pedestrian accessibility (in a neighborhood there are usually two kindergartens for 250 children and one school for 1,300 students). The unique appearance of each neighborhood was achieved by alternating 5-, 7-, 9-, and 12-story houses with public buildings. A special role was played by gallery type houses, owing to which the stylistic unity of the city was achieved during the first years of its construction. Residential areas of the city were located at a considerable distance from the industrial zone. The division of these zones allowed us to solve several problems: First, industrial enterprises are located close to each other, to the sources of raw materials, and to the energy and nodes of external transportation. Second, spatial discontinuities from the adverse effects of industrial production were ensured. Finally, it created the possibility of unimpeded growth, both for the industrial zone and for the city itself. Moreover, the residential areas were allocated the best areas of the sea coast. Thus, the city was formed in accordance with the architectural and compositional principles of full compliance with human needs and the freedom to grow along the coast of the Caspian Sea. Residential buildings were designed according to individual projects, particularly for a hot climate, namely, gallerylike buildings, with a two-way orientation of the apartments and with through-ventilation (similar to Le Corbusier, where the residential floor of the Villa Savoy in Poissy near Paris was raised using free-standing supports), and using facades with horizontal ribbon galleries and loggias, subject to the principle of strict geometrism. The proximity of the sea determined the visual infinity of the coastine for movement in space and time. This architectural idea led to the emergence of linear multi-center compositions. As time has shown, this urban planning solution turned out to be correct, and ensured the harmonious development of an urban environment. However, the problem of forming a single "facade" and the silhouette of an ensemble building, thereby creating the necessary aesthetic effect of an expressive perception of the city from the coast, particularly in the area of the city center, did not go away, and is the main solution for the future.

During the 1970s, for the design of the city of Shevchenko, the International Union of Architects presented the international architectural award, namely, the Sir Patrick Abercrombie Prize, which is called the "architectural Nobel," and is considered the most prestigious award in the field of architecture. Over the entire history of this organization, architects have received only one such award for merit in the field of urban planning in a post-Soviet space. Fitty-three cities in the world have competed for the prize, but the city of Shevchenko won. As noted in the jury protocol, the prize was awarded "for creating complex urban ensembles in difficult environmental conditions, for successfully attempting to humanize the traditional landscape by planting and irrigating the urban area" [22]. This is a reward for the reasonable activities of a person who managed to inhabit a desert.

For many years, the reasons for the failure to solve the architectural and urban planning problems in Aktau were the lack of a scientific approach toward the development of the city, a partial reorientation and closure of industrial enterprises, the absence of modern city-forming directions, and the simplicity of the space-spatial solutions, which do not reach the level of an artistic embodiment. Many beautiful high-rise residential buildings have appeared in the city; small formations in the coastal zone are interesting, but the "ensemble" of buildings has disappeared, and the stylistic and compositional unity has been broken within the boundaries of a holistic urban planning organism developed by the architects. The construction of isolated and disconnected architectural formations harms the creation of a harmonious, holistic, and spiritually saturated modern environment, disfiguring the city. Thus, architectural and artistic synthetics, which were inherent in the original project of the city, turned into an abstraction. This led not only to an impoverishment of the architectural image of the city and its urban planning but also to a disruption of the interrelationships among the functional content and spatial structure, the plastic structure of the ensemble, and the communication systems. Nowadays, fewer people are willing to waste time in traffic jams or huddle in uncomfortable apartments, and be blocked from viewing nature, which created difficulties and the death of the city. Many buildings and public complexes of Aktau, built 50 years ago, deserve status as 
Genesis and stages of renovation in architecture and urban planning of "new cities" (based on the example of Aktau (Shevchenko)

architectural works of art, i.e., monuments of architecture with a unity of content and form, considering the content of both material and spiritual function. However, the transitional period of the 1990s to the 2000s, with its chaotic investment and construction onslaught, distorted the fragile historical heritage of this city, its ecology, and everything that was deservedly appreciated by the world's architectural community.

The city needs security measures as well as fresh strategic urban planning and architectural ideas. Therefore, it was first decided to turn to one of the most modern and effective forms in developing new ideas, namely, a project workshop, as an alternative to the older planning from a design institute. This involves the collective work of experts in various directions of architecture and urban planning, along with the participation of specialists from related areas, potential participants in competitions, project coordinators, and investors. Scientific studies presented by highly qualified architects from different countries at international design seminars, aimed at analyzing existing problems and forming the main vectors of their solutions, also proposed a number of innovative ideas. The authors of the article were involved in this work as experts in their respective fields [24]. The result of the international project workshops was the discussion, preparation, and correlation of tasks for the next stages. Thus, architects, representatives of the administration, and business elites received a powerful impetus to rethink the problems of their city's perception as an effective strategy from independent professionals. The birth of new ideas occurs when testing a large number of project options. Therefore, the next crucial step is the development of conceptual, international joint projects, search, experimental, educational and other projects. A "bank of architectural ideas" at a high international level is being created for the implementation of urban planning decisions, the construction of promising housing and cultural and educational facilities, social development, business tourism, and business activities. Project winners of open competitions, which were openly discussed with the involved leadership of the region and the city, and were demonstrated at exhibitions, who received reviews in the press and were positively evaluated by the expert scientific community at subsequent international project seminars were able to participate in competitions for comprehensive renovation and development projects of the city.

Thus, a reasonable impulse was given to expanding the development of the Caspian Sea coast.

In 2007, a project called "Aktau-City" was launched, which was considered to be a logical continuation of Aktau (Shevchenko), but in fact, is an independent modern city (Figure 2).

Planning was conducted to create all conditions necessary for the development of international cooperation, the most complete realization of the tourist potential of the region, and the active recreation of the citizens. During the construction of residential complexes, all possibilities were envisaged such that each person, without leaving the neighborhood, could solve all household and social issues. Particular attention was paid to landscaping, and the creation of a park area. The project was calculated unti 2020. The estimated population is 1 million people. It also provides for the possibility of increasing the population living in Aktau City to 1.5 million. The approximate amount of investment in construction is about 40 billion US dollars. It was planned to spend about 400 million US dollars on the creation of infrastructure [25]". Because of the effects of the global crisis, the ambitious Aktau City project was suspended in 2013.

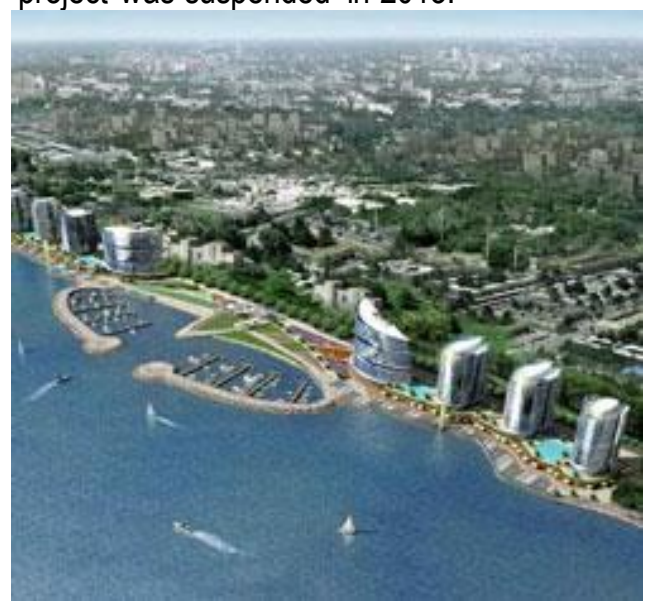

a)

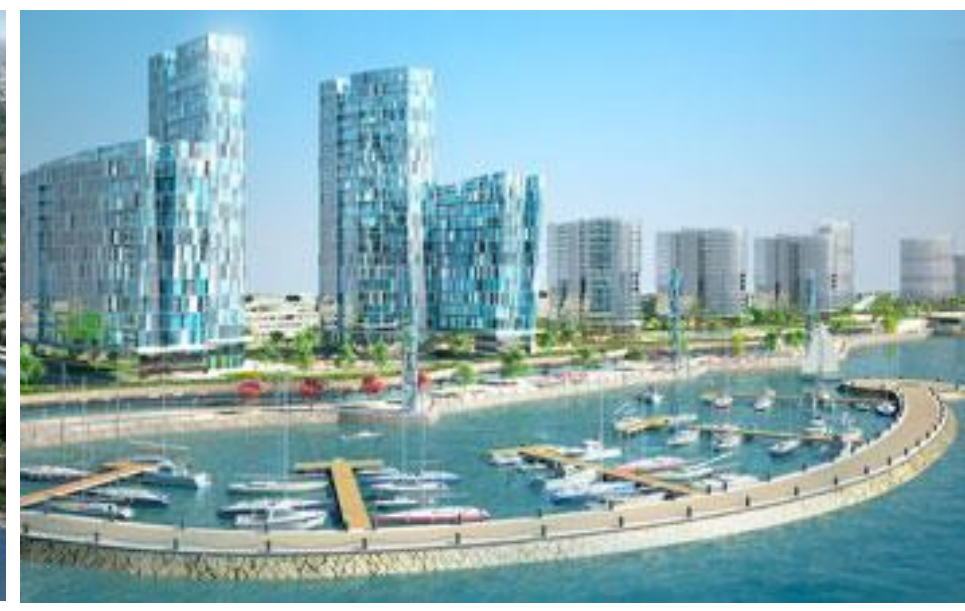

b) 
Genesis and stages of renovation in architecture and urban planning of "new cities" (based on the example of Aktau (Shevchenko)

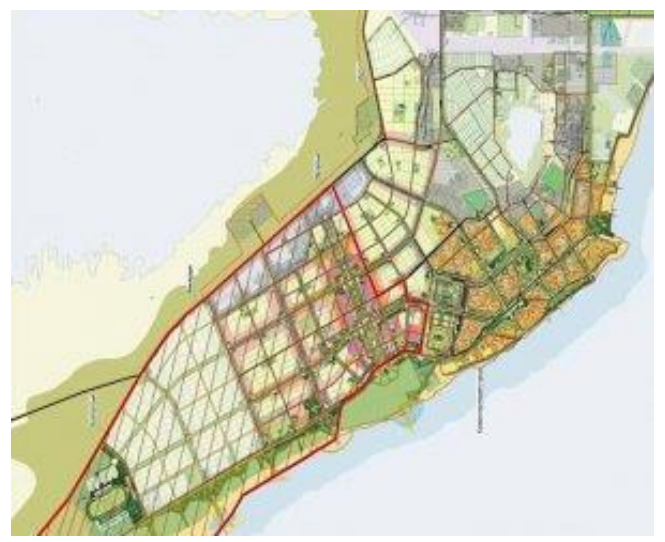

c)

Figure 2 Visualization of the Aktau City project: a) general view of the coastline [25]; b) Aktau City with yacht marina [26]; c) Area of development [26]

However, Aktau is being built and expanded not only because of the Aktau City project. At the same time, work is underway on the Kenderli tourism project. In 2017, a contract was signed for the construction and financing of the new Eco-City Aktau project. In addition, an agreement was concluded among Global Project Capital, Ltd., AAG Corporate Services, Ltd., and China Road and Bridge Corporation, Ltd. [26]. Here, with full responsibility taken, answers will be given to environmental, energy, and socio-demographic challenges. There are prospects for the development of a maritime direction, affordable housing, commercial and shopping centers, schools, kindergartens, and medical centers to be built on 865 hectares of land in the northern part of the city. According to the project, Eco-City includes an IT-park, hotels, sports stadiums, entertainment facilities, various public services, and transportation services with modern energy and eco-friendly technologies. Moreover, the modernity and artistic image of the new part of Aktau are not in conflict with the former image, and create an impression of integrity and a markedly tolerant attitude toward the older "new" city.

\section{RESULTS AND DISCUSSION}

With regard to the architecture and urban planning, it is time to research and conduct a multilateral analysis of the problems of "new" cities.

Many buildings and public complexes of cities built 50 years ago require expert evaluation, and, as in the case of Aktau (Shevchenko), deserve the status of works of art in terms of urban planning and architecture.

Today, building single fragmented architectural formations harms the creation of a harmonious, holistic, and spiritually rich environment; disfigures the city; and hinders development.

The modern strategy of such development is in the selection of the current town-forming vector, and should be based on the concepts of sustainable development with a high performance implementation.

Creative teams face the task of combining a respectful attitude and a critical evaluation regarding existing buildings, creative inspiration, and an urbanized vision with the latest scientific achievements, which is a syncretic approach toward the development and management of a modern city.

The search for new ideas and design solutions lies in scientific research, design seminars, competitive designs, and the creation of a bank of architectural and urban planning proposals. Projects that have been openly discussed, demonstrated at exhibitions, received press reviews, and positively evaluated by the expert scientific community at international project seminars can participate in competitions for their implementation toward the renovation and development of the city. 
Genesis and stages of renovation in architecture and urban planning of "new cities" (based on the example of Aktau (Shevchenko)

\section{References}

[1] Demidenko, E.S. 1992. Urbanization: the conceptand policy of urban developmentP.44. Moscow, Russia

[2] United Nations, Department of Economic and Social Affairs: $68 \%$ of the world population projected to live in urban areas by 2050, says UN, https://www.un.org/development/desa/en/news/population/2018-revision-of-world-urbanizationprospects.html, Accessed 20 May 2018

[3] Review of the EU Sustainable DevelopmentStrategy, https://wnw.etuc.org/sites/unw.etuc.org/files/st10117.en06.pdf, Accessed 3 April 2017

[4] Agile Cities. Preparing for the Fourth Industrial Revolution, https://www.weforum .org/whitepapers/agile-cities-preparingfor-the-fourth-industrial-revolution, Accessed 20 September 2018

[5] Lynch, K. 1960: The Image of the City, MIT Press, Cambridge, USA.

[6] Hillier B.; Julienne H. 1989 (reissue 2014): The Social Logic of Space, Cambridge University Press, United Kingdom.

[7] Fom in I.; Kashchenko, A. 2004: Experience and Prospects of Development of Ukrainian cities. Preparation of Architects of Urban Development, Bulletin of KNUBA, №6. Diopromisto, pp. 20-31, Kyiv, Ukraine

[8] Drapikovs'kyy, O. I.; Ivanova, I. B.; Boyko-Boychuk, O. V.;Hroysman, V. B. 2009:NADU. Urban Developmentand Urban Development Policy, Kyiv, Ukraine

[9] Habrel', M. M. 2004: Spatial Organization of City-planning Systems. Vydavnychyy dim A.S.S, Kyiv, Ukraine

[10] Didik, V.V.; Pavliv, A.P. 2006. Urban Planning. Publishing house of Lviv Polytechnic National University.

[11] Vadimov, V.M. 2013: Methodological Bases of Ecological and Urban Development of Pre-urban Urbanized Territories (in Conditions of Ukraine), Naukovyy svit, Kyiv, Ukraine.

[12] Pleshkanovs'ka, A. M.; Malyar, V.A.; Mishchenko, O. D.; Usova, O. S.; Cherednichenko, P.P. 2014: Urbanistyka, Bulletin of. KNUBA, "Arkhitekturnyy visnyk KNUBA," No. 3, pp. 184-187, Kyiv, Ukraine (in Ukrainian).

[13] Tymokhyn, V.A. 2004: Harmonyzatsyya évolyutsyonnoy dynamyky hradostroytel'nykh system. Naukovyy svit. Kyiv, Ukraine (in Ukrainian)

[14] Krivov, A. S.; Levin, M.I. 1982: Shevchenko. Architecture of the New City, Alma-Ata Publishing House, Alma-Ata, Kazakhstan.

[15] Pavlenko, T. M. 2013: Golden Placers of Memory, "Aktau-Lada TV" Publishing House, Aktau, Kazakhstan.

[16] Le Corbusier 1977: Architecture ofthe Twentieth Century, Transl. from FrenchZaitsev V.N., "Progress" Publishing House Moscow, Russia

[17] Samyye molodyye goroda Rossii, https://vivareit.ru/samye-molodye-goroda-rossii/ Accessed 20 September 2017 (in Russian).

[18] 10 samykh molodykh gorodov Ukrainy po date osnovaniya, https://hyser.com.ua/ruleconomics/93667-10-samyhmolodyh-gorodov-ukrainy-po-date-osnovaniya, Accessed 21 September 2018 (in Russian).

[19] Kranjcevic, J.; Marković, l.; Božić, N. 2016: Lički Osik - Urbanističko arhitektonsko naslijeđe moderne kao razvojni potencijal turizma, Sociologija i prostor, 54, 205 (2), pp. 103-125, https://doi.org/10.5673/sip.55.2.1 (in Croatian)

[20] Iskakov, U.M. 1992: Goroda v sisteme rasseleniya Kazakhstana (ekonomiko-demograficheskiy aspekt). Alma-Ata, Kazakhstan (in Russian).

[21] Vasil'chenko, V. 1981: Gorod v ekstremal'nykh prirodnykh usloviyakh. Arkhitektura SSSR, 6, pp. 8-21, Moscow (in Russian).

[22] Karamyshev, V.A. 1975: Gorod stroitsya v pustyne. Alma-Ata, Kazakhstan (in Russian).

[23] Priroda. Yestestvennyye resursy. Naseleniye. Ekonomika. Narodnoye blagosostoyaniye. 1989. Kazakhskaya SSR. Kratkaya entsiklopediya, 2, pp. 21, Glavnaya redaktsiya Kazakhskoy sovetskoy entsiklopedii (in Russian).

[24] Shuldan, L.O.; Lepkalyuk, M.M. 2013: Modeling of Energy-structured Development on the Example of the District of Lviv), Scientific and technical collection "Energy efficiency in construction and architecture," 5 , pp. 159-163

[25] Aktau - neftyanaya stolitsa. Kazakhstana, https://mww.kn.kz/helpful/view/id/103/, Accessed 23 April 2018 (in Russian).

[26] V Aktau postroyatunikal'nyy eko-gorod za 2,1 mlrd dollarov, https://umw.zakon.kz/4899367-v-aktau-postroyat-unikalnyeko-gorod.html, Accessed 23 March 2018 (in Russian).

Please cite this article as:

Haritonova, A.; Shuldan, L.; Shtendera, A.; Genesis and stages of renovation in architecture and urban planning of "new cities" (based on the example of Aktau (Shevchenko), Electronic Journal of the Faculty of Civil Engineering Osijek-e-GFOS, 2018, 17, pp. 24-38, https://doi.org/10.13167/2018.17.4

Haritonova, A, Shuldan, L, Shtendera, A 